Jurnal Ilmiah Matematika dan Pendidikan Matematika (JMP)

Vol. 10 No. 2, Desember 2018, hal. 1-8

ISSN (Cetak) : 2085-1456; ISSN (Online) : 2550-0422

\title{
REPRESENTASI KODE KERNEL PADA DNA
}

\author{
Isah Aisah \\ Departemen Matematika FMIPA Unpad \\ isah.aisah@unpad.ac.id \\ M. Suyudi \\ Departemen Matematika FMIPA Unpad \\ Tika Kartika \\ Departemen Matematika FMIPA Unpad
}

\begin{abstract}
Deoxyribonucleic acid (DNA) is built by several component such as group of deoxyribose sugar, group of phosphate, and group of nitrogen bases. Nitrogen bases's set can be written as $N=\{A, G, C, T\}$. Combination of three elements of $N$ form triplet codes (codon) which later are translated into amino acid during protein synthesis process. During amino acid forming process, sometimes error can occurs and change something. This error is called gene mutation. There are several gene mutations, one of them is point mutation. This mutation is caused by one change of nitrogen base in a DNA sequence.Gene mutation can be represented by using several ways. One of them is using Kernel code's representation. This representation is gained by constructing a homomorphism of cross product of group $N$ (DNA sequences's group) to another comutative group. Kernel of this homomorphism is called kernel code, and its elements represent normal DNA sequences.
\end{abstract}

Keyword : cross product, genetic, group homomorphism, kernel code, gene mutation.

ABSTRAK. DNA (deoxyribonucleic acid,) terdiri dari beberapa komponen yaitu gugus gula deoksiribosa, gugus fosfat, dan gugus basa nitogren. Himpunan basa nitrogen dapat ditulis sebagai $N=\{A, G, C, T\}$. Kombinasi dari tiga buah elemen $N$ membentuk kode triplet (kodon) yang ditranslasikan menjadi asam amino dalam proses sintesis protein. Dalam penyusunan asam amino dapat terjadi suatu kesalahan atau disebut mutasi gen. Terdapat beberapa jenis mutasi gen, salah satunya adalah mutasi titik. Mutasi titik terjadi akibat perubahan satu buah basa nitrogen pada suatu barisan DNA. Dalam kajian matematika, mutasi gen khususnya mutasi titik dapat direpresentasikan melalui berbagai cara, salah satunya adalah menggunakan representasi kode kernel. Representasi ini diperoleh dengan cara mengkonstruksi pemetaan yang bersifat homomorfisma dari cross product grup $N$ (grup barisan $D N A$ ) terhadap suatu grup komutatif. Kernel dari pemetaan tersebut disebut kode kernel. Elemen-elemen dari kode kernel merepresentasikan barisan DNA normal.

Kata Kunci : cross product, genetik, homomorfisma grup, kode kernel, mutasi gen. 


\section{PENDAHULUAN}

Himpunan basa Nitrogen dapat disajikan sebagai $N=\{A, G, C, T\}$. Kombinasi dari tiga buah elemen $N$ membentuk kode triplet (kodon) yang ditranslasikan menjadi asam amino dengan proses sintesis protein. Kode triplet (kodon) disebut sebagai kode genetik standar. Kombinasi hingga dari elemen $N$ membentuk suatu barisan DNA. Himpunan barisan DNA tersebut dapat disajikan sebagai cross product himpunan $N$ atau

$$
N \times N \times N \times \cdots \times N=\left\{a_{1} a_{2} a_{3} \ldots a_{n} \mid a_{1}, a_{2}, a_{3}, \ldots, a_{n} \in N\right\} .
$$

Mutasi gen dalam kajian Matematika dapat direpresentasikan dengan berbagai cara, salah satu cara yang dapat digunakan adalah dengan kode kernel. Kode kernel dapat didefinisikan sebagai kernel dari cross product grup yang dipetakan secara homomorfisma terhadap suatu grup. Permasalahan yang muncul, bagaimana mengkonstruksi pemetaan yang homomorfisma dari cross product himpunan $N$ terhadap $\mathbb{Z}_{2}$, sehingga dapat diperoleh manfaatnya yaitu dapat mengkaji representasinya pada suatu penyakit anemia sel sabit.

\section{HASIL DAN PEMBAHASAN}

Langkah pertama yang akan dilakukan dalam penelitian ini adalah mengaitkan himpunan basa nitrogen $N$ terhadap $\mathbb{Z}_{4}$. Pengaitan ini dilakukan untuk mengetahui struktur dan operasi yang ada pada himpunan basa nitrogen $N$. Setelah mengetahui struktur dari himpunan basa nitrogen $N$, kemudian dilakukan penentuan struktur dari cross product himpunan basa nitrogen $N$ atau $N \times N \times$ $\ldots \times N$.

Selanjutnya akan dikonstruksi pemetaan yang bersifat homomorfisma dari himpunan $N$ ke $\mathbb{Z}_{2}$. Pemetaan ini akan menjadi dasar dari pemetaan selanjutnya yakni pemetaan pada kodon dan barisan DNA. Selanjutnya akan dikonstruksi pemetaan yang bersifat homomorfisma dari himpunan kodon ke $\mathbb{Z}_{2}$. Berikutnya akan dikonstruksi pemetaan yang bersifat homomorfisma dari barisan DNA dengan jumlah basa nitrogen 18 buah (6 kodon) ke $\mathbb{Z}_{2}$, kemudian dilakukan perhitungan kode kernel dari pemetaan tersebut. 


\subsection{Struktur Himpunan Basa Nitrogen}

DNA terdiri dari dua jenis basa nitrogen, yakni Purin yang terdiri dari Adenin (A) dan Guanin (G), serta Pirimidin yang terdiri dari Sitosin (C) dan Timin (T). Keempat basa nitrogen tersebut dapat dibuat ke dalam suatu himpunan $N=\{A, T, G, C\}$. Himpunan $N$ dengan suatu operasi biner dapat dilihat struktur aljabarnya. Perhatikan tabel cayley berikut:

Tabel 1. Tabel Cayley

\begin{tabular}{|c|c|c|c|c|}
\hline+ & $A$ & $C$ & $G$ & $T$ \\
\hline$A$ & $A$ & $C$ & $G$ & $T$ \\
\hline$C$ & $C$ & $G$ & $T$ & $A$ \\
\hline$G$ & $G$ & $T$ & $A$ & $C$ \\
\hline$T$ & $T$ & $A$ & $C$ & $G$ \\
\hline
\end{tabular}

Berdasarkan Tabel 1, maka dapat disimpulkan :

1. $\quad N$ tertutup terhadap penjumlahan;

2. $\quad N$ asosiatif terhadap penjumlahan;

3. $N$ memiliki elemen identitas yaitu $A$

4. Setiap elemen $N$ memiliki invers yaitu $(A)^{-1}=A,(C)^{-1}=T,(G)^{-1}=$ $G, \operatorname{dan}(T)^{-1}=C$

5. $N$ komutatif terhadap penjumlahan.

Dari $1-5, N$ merupakan grup komutatif.

Selanjutnya akan dilakukan pencocokan dari grup basa nitrogen $N=$ $\{A, T, G, C\}$ terhadap $\mathbb{Z}_{4}=\{\overline{0}, \overline{1}, \overline{2}, \overline{3}\}$ agar diketahui sejauh mana kemiripan struktur dari kedua buah grup tersebut. Grup $\mathbb{Z}_{4}$ sendiri dipilih karena memiliki jumlah elemen yang sama dengan grup $N$ yakni sebanyak 4 buah.

Konstruksi pemetaan $f: N \rightarrow \mathbb{Z}_{4}$ dengan :

$$
\begin{aligned}
f: N & \rightarrow \mathbb{Z}_{4} \\
A & \mapsto \overline{0} \\
T & \mapsto \overline{1}
\end{aligned}
$$




$$
\begin{aligned}
& G \mapsto \overline{2} \\
& C \mapsto \overline{3}
\end{aligned}
$$

Dengan pengaitan tersebut, dapat dibuktikan bahwa $f$ merupakan pemetaan yang isomorfisma. Dengan demikian $N \cong \mathbb{Z}_{4}$. Selanjutnya, akan didefinisikan struktur dari Cross Product Himpunan Basa Nitrogen.

Kombinasi dari himpunan-himpunan basa nitrogen membentuk suatu barisan DNA atau dapat ditulis menjadi himpunan $N \times N \times N \times \ldots \times N=$ $\left\{x_{1} x_{2} x_{3} \ldots x_{n} \mid x_{i} \in N\right\}$. Dengan $N$ merupakan grup komutatif, akan diselidiki struktur himpunan $N \times N \times N \times \ldots \times N=\left\{x_{1} x_{2} x_{3} \ldots x_{n} \mid a_{i} \in N\right\}$ secara aljabar. Definisikan himpunan barisan DNA sebagai $M=N \times N \times \ldots \times N=$ $\left\{x_{1} x_{2} x_{3} \ldots x_{n} \mid x_{i} \in N\right\}$. Dengan menggunakan aksioma grup, maka $M$ merupakan grup komutatif terhadap penjumlahan.

Selanjutnya akan dilakukan pencocokan basa Nitrogen terhadap $\mathbb{Z}_{\mathbf{2}}$, dengan terlebih dahulu mengkonstruksi pemetaan dari $N$ terhadap $\mathbb{Z}_{\mathbf{2}}$. Basa nitrogen terdiri dari purin dan pirimidin, sehingga basa nitrogen dapat dipetakan terhadap $\mathbb{Z}_{2}$, yakni purin dikaitkan terhadap $\overline{0}$ dan pirimidin dikaitkan terhadap $\overline{1}$. Dengan demikian dapat dikonstruksi pemetaan sebagai berikut :

Definisikan pemetaan

$$
\begin{gathered}
\varphi: N \rightarrow \mathbb{Z}_{2} \\
\text { dengan } \varphi(\mathrm{A})=\varphi(\mathrm{G})=\overline{0}, \varphi(\mathrm{C})=\varphi(\mathrm{T})=\overline{1} .
\end{gathered}
$$

Dengan menggunakan definisi homomorfisma grup maka dapat disimpulkan $\varphi: N \rightarrow \mathbb{Z}_{2}$ merupakan homomorfisma grup. Pengaitan di atas merupakan salah satu contoh yang memenuhi sifat homomorfisma grup.

\subsection{Pencocokkan Kodon terhadap $\mathbb{Z}_{2}$}

Kombinasi dari tiga buah elemen himpunan basa nitrogen $N$ membentuk kode triplet atau kodon yang selanjutnya mengkodekan asam amino. Dengan menggunakan pemetaan $N$ terhadap $\mathbb{Z}_{2}$, selanjutnya akan dikonstruksi pemetaan kodon terhadap $\mathbb{Z}_{2}$ dan dicari kode kernel dari pemetaan tersebut. Elemen dari kode kernel yang diperoleh akan merepresentasikan kodon-kodon normal pada DNA. Definisikan pemetaan 


$$
\varphi: N \times N \times N \rightarrow \mathbb{Z}_{2}
$$

sebagai $\varphi(x y z)=\varphi_{1}(x) \varphi_{2}(y) \varphi_{3}(z)$ dengan $\varphi_{i}: N \rightarrow \mathbb{Z}_{2}$ homomorfisma grup, $\operatorname{dan} \varphi_{i}(A)=\varphi_{i}(G)=\overline{0}, \varphi_{i}(C)=\varphi_{i}(T)=\overline{1}$.

Kodon pada himpunan $N N N$ dapat dibagi menjadi dua kelompok yaitu :

1. Kodon dengan banyaknya basa nitrogen purin $(A, G)$ berjumlah genap dan basa nitrogen pirimidin $(C, T)$ berjumlah ganjil. Selanjutnya, kelompok kodon ini disebut kelompok (a).

2. Kodon dengan banyaknya basa nitrogen purin $(A, G)$ berjumlah ganjil dan basa nitrogen pirimidin $(C, T)$ berjumlah genap. Selanjutnya, kelompok kodon ini disebut kelompok (b).

Akibatnya, kodon dapat dipetakan terhadap $\mathbb{Z}_{2}$ yakni kodon yang termasuk kelompok (a) dipetakan terhadap $\overline{1}$ sedangkan kodon yang termasuk kelompok (b) dipetakan terhadap $\overline{0}$. Dengan demikian dapat dikontruksi pemetaan dari $N \times N \times$ $N$ ke $\mathbb{Z}_{2}$ dengan pengaitan sebagai berikut :

\begin{tabular}{|c|c|c|c|}
\hline $\mathrm{AAA} \mapsto \overline{0}$ & $\mathrm{ATG} \mapsto \overline{1}$ & $\mathrm{CCG} \mapsto \overline{0}$ & $\mathrm{GGC} \mapsto \overline{1}$ \\
\hline $\mathrm{AAC} \mapsto \overline{1}$ & $\mathrm{AGT} \mapsto \overline{1}$ & $\mathrm{CGC} \mapsto \overline{0}$ & $\mathrm{GCG} \mapsto \overline{1}$ \\
\hline $\mathrm{ACA} \mapsto \overline{1}$ & $\mathrm{GAT} \mapsto \overline{1}$ & $\mathrm{GCC} \mapsto \overline{0}$ & $\mathrm{CGG} \mapsto \overline{1}$ \\
\hline $\mathrm{CAA} \mapsto \overline{1}$ & $\mathrm{GTA} \mapsto \overline{1}$ & $\mathrm{CCT} \mapsto \overline{1}$ & GGT $\longmapsto$ \\
\hline $\mathrm{AAG} \mapsto \overline{0}$ & $\mathrm{TGA} \mapsto \overline{1}$ & $\mathrm{CTC} \mapsto \overline{1}$ & $\mathrm{GTG} \mapsto \overline{1}$ \\
\hline $\mathrm{AGA} \mapsto \overline{0}$ & $\mathrm{TAG} \mapsto \overline{1}$ & $\mathrm{TCC} \mapsto \overline{1}$ & $\mathrm{TGG} \mapsto$ \\
\hline $\mathrm{GAA} \mapsto \overline{0}$ & $\mathrm{ATC} \mapsto \overline{0}$ & $\mathrm{CGT} \mapsto \overline{0}$ & TTT $\longmapsto$ \\
\hline $\mathrm{AAT} \longmapsto \overline{1}$ & $\mathrm{ACT} \mapsto \overline{0}$ & $\mathrm{CTG} \mapsto \overline{0}$ & $\mathrm{TTA} \mapsto \overline{0}$ \\
\hline $\mathrm{ATA} \mapsto \overline{1}$ & $\mathrm{CAT} \mapsto \overline{0}$ & $\mathrm{GCT} \mapsto \overline{0}$ & $\mathrm{TAT} \mapsto \overline{0}$ \\
\hline $\mathrm{TAA} \mapsto \overline{1}$ & $\mathrm{CTA} \mapsto \overline{0}$ & $\mathrm{GTC} \mapsto \overline{0}$ & $\mathrm{ATT} \mapsto \overline{0}$ \\
\hline $\mathrm{AGC} \mapsto \overline{1}$ & $\mathrm{TAC} \mapsto \overline{0}$ & TCG $\longmapsto \overline{0}$ & $\mathrm{TTC} \mapsto$ \\
\hline $\mathrm{ACG} \longmapsto \overline{1}$ & $\mathrm{TCA} \mapsto \overline{0}$ & $\mathrm{TGC} \mapsto \overline{0}$ & $\mathrm{TCT} \mapsto 1$ \\
\hline $\mathrm{CAG} \mapsto \overline{1}$ & $\mathrm{CCC} \mapsto \overline{1}$ & $\mathrm{GGG} \mapsto \overline{0}$ & $\mathrm{CTT} \mapsto \overline{1}$ \\
\hline $\mathrm{CGA} \mapsto \overline{1}$ & $\mathrm{CCA} \mapsto \overline{0}$ & $\mathrm{GGA} \mapsto \overline{0}$ & $\mathrm{TTG} \mapsto \overline{0}$ \\
\hline $\mathrm{GAC} \mapsto \overline{1}$ & $\mathrm{CAC} \mapsto \overline{0}$ & $\mathrm{GAG} \longmapsto \overline{0}$ & $\mathrm{TGT} \mapsto \overline{0}$ \\
\hline $\mathrm{GCA} \mapsto \overline{1}$ & $\mathrm{ACC} \mapsto \overline{0}$ & $\mathrm{AGG} \mapsto \overline{0}$ & $\mathrm{GTT} \longmapsto$ \\
\hline
\end{tabular}

Dengan $\quad$ demikian, $\quad \varphi: N \times N \times N \rightarrow \mathbb{Z}_{2} \quad$ dengan $\varphi(x y z)=\varphi_{1}(x) \varphi_{2}(y) \varphi_{3}(z)$ merupakan pemetaan yang bersifat homomorfisma grup. 
Selanjutnya, akan ditentukan kernel dari pemetaan tersebut yaitu $\operatorname{Ker} \varphi=$ $\left\{(x y z) \in N \times N \times N \mid \varphi(x y z)=\overline{0} \in \mathbb{Z}_{2}\right\}$.

Dari pengaitan di atas maka elemen-elemen kode kernel dapat disajikan dalam bentuk tabel seperti berikut

Tabel 2. Tabel Kode Kernel dari Pemetaan $\varphi$

\begin{tabular}{|c|c|c|c|c|c|c|c|}
\hline AAA & CCG & TGT & GTC & CCA & TAT & ATC & GGG \\
\hline AAG & CGC & GTT & GCT & CAC & ATT & ACT & GGA \\
\hline AGA & CGG & TCG & CGT & ACC & TCA & CAT & GAG \\
\hline GAA & TTG & TGC & CTG & TTA & TAC & CTA & AGG \\
\hline
\end{tabular}

Selanjutnya dapat dilihat bahwa kode kernel bersifat siklis. Sebagai contoh :

a. AAG bentuk siklisnya adalah GAA dan merupakan elemen kode kernel.

b. TCA bentuk siklisnya adalah ATC dan merupakan elemen kode kernel.

Dengan demikian seluruh anggota Kode Kernel bersifat Siklis. Selain itu, seluruh anggota kode kernel bersifat reversible. Sebagai contoh :

a. CTG bentuk reversibelnya adalah GTC dan merupakan elemen kode kernel.

b. TCA bentuk reversibelnya adalah ACT dan merupakan elemen kode kernel.

\section{KESIMPULAN DAN SARAN}

Berdasarkan uraian di atas, dapat disimpulkan bahwa kode kernel diperoleh melalui pemetaan tertentu yang bersifat homomorfisma dari barisan DNA ke suatu grup komutatif. Dari kode kernel yang diperoleh, dapat pula diselidiki sifat-sifatnya yaitu bersifat siklis dan reversible. 


\section{DAFTAR PUSTAKA}

Elrod, S. dan Stansfield, W., Schaum's Outlines : Genetika, Terjemahan oleh Damaring Tyas W., Penerbit Erlangga, Jakarta, 2002.

Judson, T. W. dan Stephen F., Abstract Algebra : Theory and Application, Austin State University, 2011.

Jose, M. V. R., Morgado, E., Sanchez, R., dan Govezensky, T., The 24 Possible Algebraic Representation of the Standard Genetic Code in Six or Three Dimensions, Advanced Studies in Biology, 119-152, 2012.

Herstein, I. N., Topic in Algebra : Third Edition, Ginn and Company, London, 1995.

Marks, A. D., Smith, C., dan Lieberman, M., Basic Medical Biochemistry : A Clinical Approach, Second Edition, Lippincott William and Wilkins, 2005.

Pai, A. C., Dasar-Dasar Genetika, Terjemahan oleh Muchidin Apanndi, Penerbit Erlangga, Jakarta, 2006.

Priyani, N., Sifat Fisik dan Kimia DNA, Program Studi Biologi, Universitas Sumatera Utara, 2004.

Sanchez, R., Morgado, E., dan Grau, R., The Genetic Code Boolean Lattice, Journal of MATCH Commun. Math. Comput, 52 (2004), 29-46.

Selvakumar, R., Kernel Code and Its Controllability, Journal of Discrete Mathematical Sciences and Cryptography, 2014, 98-101. 
